\title{
Energy cost of cattle walking on the level and on a gradient
}

\author{
O.N. DI MARCO AND M.S. AELLO
}

Authors are professors of animal nutrition at the Agricultural Science College of the National University of Mar del Plata, Department of Animal Science, CC 276, (7620) Balcarce, Argentina.

\section{Abstract}

The effect of walking on cattle energy expenditure was assessed by monitoring the $\mathrm{CO}_{2}$ production of cattle with the ${ }^{14} \mathrm{C}$-entry rate technique. Seven Angus steers $(298 \pm 38 \mathrm{~kg} \mathrm{BW}$ ) were peritoneally infused with a solution of $\mathrm{NaH}^{14} \mathrm{CO}_{3}$ for 72 hours using portable peristaltic pumps. The steers were forced to walk after 24 hours of infusion, on 2 consecutive days. On the first day, walking was at a constant speed of 2 $\mathrm{km} . h o u r^{-1}$, divided in 4 periods of 0.5 hours $(1 \mathrm{~km})$, first on the level ground, second and third ascending and descending a $6 \%$ grade, and finally on the level surface on the way back to corrals. On the second day, cattle walked $1 \mathrm{~km}$ at $1 \mathrm{~km}$ hour $^{-1}$, and thereafter walked $4 \mathrm{~km}^{\text {at }} 4 \mathrm{~km} \mathrm{hour}^{-1}$ on the level. Saliva samples were collected for periods of 0.5 hours before and during different periods of walking and at rest at 2 and 4 hours after the activity. Concentration and specific activity of $\mathrm{CO}_{2}$ were measured in saliva samples to estimate the rate of $\mathrm{CO}_{2}$ production [ml.hour ${ }^{-1} .\left(\mathrm{BW}^{0.75}\right)^{-1}$ ] as the ratio between the rate of infusion $\left(\mu \mathrm{Ci}\right.$.hour $\left.{ }^{-1}\right)$ and the specific activity of $\mathrm{CO}_{2}\left(\mu \mathrm{Ci}\right.$.liter-1 of $\left.\mathrm{CO}_{2}\right)$. The production of $\mathrm{CO}_{2}$ was converted to heat production using an energy equivalent of 5.26 kcal.liter $^{-1}$. Average energy expenditure (EE) in corrals in both days before the activity was $82.6 \pm 3.1 \mathrm{kcal}$ hour ${ }^{1} .100 \mathrm{~kg} \mathrm{BW}^{-1}\left[650 \mathrm{ml} \mathrm{CO}_{2} \cdot \mathrm{hour}^{-1} .\left(\mathrm{BW}^{0.75}\right)^{-1}\right]$. The cost of walking on the level surface and on the $6 \%$ grade was $9.0 \pm 1.14$

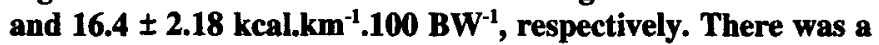
small nonsignificant residual effect of walking that disappeared a few hours after exercise. It was concluded that the cost of walking can only have a minor effect on the energy requirement of grazing cattle.

Key Words: voluntary activity, energy expenditure, carbon dioxide entry rate

Freely grazing cattle spend most of the day harvesting forage and walking, consequently it has been assumed that the extra energy expenditure on pastoral systems may affect production of beef or dairy cattle. Daily, cattle could spend 8 to 10 hours grazing and would walk between 2 to $8 \mathrm{~km}$ (Herbel and Nelson 1966,

\footnotetext{
This experiment is part of the project "Factors affecting energy expenditure of grazing cattle" supported by the University of Mar del Plata, CONICET and INTA of Argentina.

Manuscript accept 26 Feb. 1997.
}

El efecto de la caminata sobre el gasto energético de vacunos fue evaluado a través de la producción de $\mathrm{CO}_{2}$, estimada por la tasa de dilución del radiocarbono $\left({ }^{14} \mathrm{C}\right)$. Siete novillos Angus (298 $\pm 38 \mathrm{~kg}$ peso corporal) se infundieron intra-peritonealmente con una solución de $\mathrm{NaH}^{14} \mathrm{CO}_{3}$ durante $72 \mathrm{~h}$, utilizando bombas peristálticas portátiles. Los novillos se hicieron caminar durante dos días consecutivos, comenzando la actividad después de 20 h del inicio de la infusión. El primer día, la caminata se realizó a una velocidad constante de $2 \mathrm{~km} \cdot \mathrm{h}^{-1}$, en cuatro periodos de $0,5 \mathrm{~h}(1 \mathrm{~km})$. Primero caminaron en el llano, segundo subiendo una loma de $6 \%$ de pendiente, tercero bajando la misma y, finalmente, volvieron a caminar en el llano para volver a los corrales, donde descansaron hasta el próximo día. El segundo día caminaron en el lano, primero recorriendo una distancia de $1 \mathrm{~km}$ a una velocidad de $1 \mathrm{~km} \mathrm{~h}^{-1} \mathrm{y}$, posteriormente, sobre una distancia de $4 \mathrm{~km}$ a una velocidad de $4 \mathrm{~km} \cdot \mathrm{h}^{-1}$. Se colectaron muestras de saliva durante períodos de 0,5 h antes, durante los diferentes períodos de actividad, y a las 2 y 4 h de descanso después de la misma. Se midió la concentración y actividad específica (AE) del $\mathrm{CO}_{2}$ en las muestras de saliva, para estimar la producción de $\mathrm{CO}_{2}\left[\mathrm{ml} \mathrm{h}^{-1} \cdot(\mathrm{kg0}, 75)^{-1}\right]$. Esta se calculó como la relación entre la tasa de infusión $\left(\mu \mathrm{Ci}^{-1} \mathrm{~h}^{-1}\right)$ y la $\mathrm{AE}$ del $\mathrm{CO}_{2}\left(\mu \mathrm{Ci} . \mathrm{I}^{-1}\right.$ de $\left.\mathrm{CO}_{2}\right)$. La producción de $\mathrm{CO}_{2}$ se convirtió en calor, utilizando como equivalente energético del $\mathrm{CO}_{2}$ el valor 5,26 kcal. $\mathbf{1}^{-1}$. El promedio de gasto energético en corral durante los dos días, previo a la actividad, fue de 82,6 $\pm 3,1$

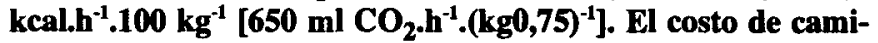
nar en el llano y en la loma de $6 \%$ de pendiente fue de $9,0 \pm$ 1,14 y $16,4 \pm 2,18 \mathrm{kcal} \mathrm{km}^{-1} .100 \mathrm{PV}^{-1}$, respectivamente. Hubo un pequeño $y$ no significativo efecto residual de la caminata que desapareció unas pocas horas después del ejercicio. Se concluyó que el costo de la caminata solamente puede tener un efecto de poca importancia en los requerimientos energéticos de vacunos en pastoreo.

Ribeiro et al. 1977, Aello and Gómez 1984, Lathrop et al. 1988, Hart et al. 1993).

Energy expenditure of grazing cattle has been investigated by various workers during the last 20 years. Most estimations of energy cost of walking in cattle are derived from experiments with sheep (Clapperton 1964, Graham 1964), or from the study of Ribeiro et al. (1977) with cattle. Data from calorimeters or respi- 
ration chambers indicate that walking may considerably increase the requirement of maintenance. For example Ribeiro et al. (1977) estimated, from data of cattle walking on a treadmill, that animals travelling between 1 to $6 \mathrm{~km}$ could increase energy requirement by about 4 to $24 \%$ above maintenance. These workers measured $\mathrm{O}_{2}$ consumption of 4 steers walking on a treadmill at speeds between 2 to $5 \mathrm{~km}$ hour ${ }^{-1}$, concluding that the average energy cost for walking in cattle was about $50 \mathrm{kcal} . \mathrm{km}^{-1} .100 \mathrm{~kg} \mathrm{BW}^{-1}$ as it has been reported in sheep (Clapperton 1964, Graham 1964).

It is important to remark that research on the energetic cost of cattle walking on the open range has been limited by available methodologies, and also because measurement depends on observations of an increase in heat production that is often small in relation to that standing still (Farrell et al. 1972). Therefore, values from 45 to $60 \mathrm{kcal}^{\mathrm{km}} \mathrm{km}^{-1} .100 \mathrm{~kg} \mathrm{BW}^{-1}$ have been generally accepted for unrestrained cattle walking on the open range (Osuji 1974, ARC 1980, CSIRO 1990). Consequently it has been assumed that if walking has such high energy cost, the reduction of the distance travelled could save energy and improve production.

Graham (1964) suspected that animals on a treadmill could exhibit a higher energy expenditure than those walking in the open range and many researchers have not found that walking per se effected animal performance, or that the effect was much lower than expected. For example Thomson and Barnes (1993) did not find a negative effect on milk production of dairy cattle travelling $8 \mathrm{~km}$ day $^{-1}$, even though their cows walked part of that distance over a $15 \mathrm{~m}$ hill. Lamb et al. (1979) found that walking improved reproductive and feeding efficiency without affecting production, in 2-year-old dairy heifers that have been kept in confinement. Gemeda et al. (1995) reported minor differences in body weight losses and milk production between working and non-working cows. Nicholson (1987) found that the effect of long-term walking on zebu cattle productivity was negligible. $\mathrm{He}$ concluded that the additional energy requirements for walking are very small and lower than those reported in the literature. In addition, Méndez et al. (1996) estimated from the carbon dioxide dilution rate technique that cattle walking between 6 to $9 \mathrm{~km}_{\text {day }}{ }^{-1}$ at $3 \mathrm{~km} \mathrm{hour}^{-1}$ would increase energy expenditure by only 4 to $6 \%$. Findings cited above indicate that the energy cost of walking on the open range may be lower than those on treadmills, which cast doubts on the negative effect of this extra energy cost on grazing cattle production.

This research was conducted to evaluate the energy cost of free-walking cattle travelling on the level at speeds of 1,2 , and 4 $\mathrm{km} \mathrm{hour}^{-1}$, on a $6 \%$ gradient at $2 \mathrm{~km}$ hour ${ }^{-1}$, and standing still before and after 2 and 4 hours of the exercise, using the carbon dioxide dilution rate technique (Whitelaw 1974, White 1993).

\section{Materials and Methods}

\section{Carbon Dioxide Entry Rate Technique}

Energy expenditure of walking cattle was evaluated in the fall of 1995 , in Balcarce, Argentina ( $37^{\circ} 45^{\prime}$ south, $58^{\circ} 18^{\prime}$ west), from the $\mathrm{CO}_{2}$ production estimated by the $\mathrm{CO}_{2}$ entry rate technique (Young 1970).

A solution of $\mathrm{NaH}^{14} \mathrm{CO}_{3}$ (American Radiolabeled Inc., $\mathrm{pH}=10$ ) was infused at a rate of $8.1 \mu \mathrm{Ci}$ hour ${ }^{-1}$ for 72 hours using individual battery-powered peristaltic pumps (Syropum, Everest Electronic, Australia). The pumps were carried in a canvas pouch on a wither harness. Saliva was drained manually from a parotid salivary duct cannula directly into a plastic flask attached to the cattle neck. Samples were collected before and during different periods of walking, and at rest 2 and 4 hours after the activity. Sampling commenced at least 20 hours after the infusion was started (Sanchez and Morris 1984) and over periods of $30 \mathrm{~min}$ utes to provide an integrated value of specific activity of $\mathrm{CO}_{2}$ over the period the exercise was performed.

The specific activity of $\mathrm{CO}_{2}$ was calculated in saliva samples dividing the activity ( $\mu \mathrm{Ci}$.ml ${ }^{-1}$ saliva) by the concentration of $\mathrm{CO}_{2}$ in the samples of saliva ( $\mathrm{ml} \mathrm{CO} 2 \cdot \mathrm{ml}^{-1}$ saliva). Carbon dioxide concentration was determined by Neiss's technique (Sahlu et al. 1988) and ${ }^{14} \mathrm{C}$-activity was measured in $1 \mathrm{ml}$ of saliva, mixed with $9 \mathrm{ml}$ of a scintillation cocktail. In each case determinations were made in triplicate.

Carbon dioxide production rate was calculated as the ratio between the infusion rate $\left(\mu \mathrm{Ci}\right.$ hour $\left.{ }^{-1}\right)$ and the specific activity of $\mathrm{CO}_{2}\left(\mu \mathrm{Ci}\right.$ liter ${ }^{-1}$ of $\mathrm{CO}_{2}$ ) (Corbett et al. 1971), and was expressed as $\mathrm{ml}$ of $\mathrm{CO}_{2}$ hour ${ }^{-1}\left(\mathrm{~kg}^{0.75}\right)^{-1}$. Heat Production (HP) was estimated assuming an energy equivalent of $5.26 \mathrm{kcal}_{\text {liter }}^{-1}$ of $\mathrm{CO}_{2}$ (derived from data of Sahlu et al. 1988, and Elia et al. 1988).

Angus steers, 18 to 20 months of age, were placed in individual corrals for 1 week and fed alfalfa hay (1 kg DM.100 kg BW B $^{-1}$ ) and also allowed to graze 2 hours day ${ }^{-1}$. During this adaptation phase the steers were tamed and trained to walk following a tractor at a constant speed. Animals were prepared for infusion of ${ }^{14} \mathrm{C}$ and saliva sampling, placing 1 catheter into the peritoneal cavity, and another into 1 parotid gland duct, which exited the mouth via a perforation in the cheek (as described by Sanchez and Morris 1984, and Salhu et al. 1988).

\section{Field Experiment}

For 2 days, 7 steers, 3 of small size $(258 \pm 14.9 \mathrm{~kg} \mathrm{BW})$ and 4 of medium size $(327 \pm 6.4 \mathrm{~kg} \mathrm{BW})$, walked following a tractor at a constant speed over a predetermined distance. The exercise was performed under fall weather conditions with mild temperature and high humidity. Temperature averages were $\left({ }^{\circ} \mathrm{C}\right) 18.2$ with a minimum of 13.4 and a maximum of 23.0 . In both days a short rainfall was registered in the morning.

On day 1 , the steers were allowed to graze 2 hours in the morning and thereafter walked at $2 \mathrm{~km}$ hour ${ }^{-1}$ for 4 distance intervals of $1 \mathrm{~km}$ each ( 30 minutes). First interval was on the level ground, the second and third interval ascended and descended a $6 \%$ grade, and the fourth interval was on the level ground on the way back to corrals. The second day, they walked a distance of $1 \mathrm{~km}$ at 1 $\mathrm{km}$ hour $^{-1}$, and thereafter $4 \mathrm{~km}$ at $4 \mathrm{~km}$ hour ${ }^{-1}$ (intervals of 1 hour each) on level ground. Saliva samples were taken over a period of 30 minutes on each walking interval and also replicated samples were taken during the 1 hour-walking interval at $4 \mathrm{~km}$ hour ${ }^{-1}$. Additionally, saliva was taken before the activity of each day, and after 2 and 4 hours after the activity.

\section{Statistical Analysis}

Walking energy cost on the level ground ( $\left.\mathrm{kcal} \mathrm{km}^{-1}\right)$ was estimated by linear regression using speed $\left(0,1,2\right.$, and $\left.4 \mathrm{~km} . \mathrm{hour}^{-1}\right)$ as the independent variable and energy expenditure (kcal.hour ${ }^{-1} .100 \mathrm{~kg}$ $\mathrm{BW}^{-1}$ ) as dependent variable. Energy cost of walking on the $6 \%$ grade was calculated by the average increase of EE walking on the grade (ascending and descending) relative to that observed in corrals (kcal hour $\left.{ }^{-1}\right)$, divided by the distance travelled $(2 \mathrm{~km})$. Mean standard errors were computed in each case. Comparison of EE between both days in corrals before activity, walking at 2 
$\mathrm{km}$.hour ${ }^{-1}$ before and after walking on the grade, ascension vs descension of the grade, resting 2 and 4 hours after the activity, and within the period of 1 hour walking at $4 \mathrm{~km}$ hour ${ }^{-1}$, was analyzed by 1 way ANOVA ( $\mathrm{p}<0.1)$ and significant F-means were tested by Fisher's (LSD) test.

\section{Results and Discussion}

\section{Application of ${ }^{14} \mathrm{C}$ entry rate technique}

Steers adapted well to the experimental protocol and no technical problems were detected during the 3 days of continuous infusion of ${ }^{14} \mathrm{C}$, or during saliva collection. It was very important to work with tamed and trained animals to collect saliva without altering normal behavior of cattle. With a catheter properly placed in the parotid duct, saliva was collected continuously while cattle were walking or standing still without disturbing them. It was also mandatory to use proper portable peristaltic pumps, that assured ${ }^{14} \mathrm{C}$ infusion at a constant rate under field conditions during the 3 days of the study.

Saliva sampling from the parotid gland was chosen because it appeared to be easier and less stressful than continuous blood sampling. Engels et al. (1976) reported also greater precision in estimating energy expenditure from entry rate data derived from saliva than from urine or blood, and Whitelaw (1974) pointed out that this technique estimates $\mathrm{CO}_{2}$ production with high precision, showing only minor differences with estimations on respiration chambers (Sahlu et al. 1988) and with the advantage of not disturbing animals on the open range. Saliva is secreted continuously and its bicarbonate content $\left(\mathrm{CO}_{2}\right)$ equilibrates with all extracellular bicarbonate in the rest of the body causing changes of $\mathrm{CO}_{2}$ production rapidly (Whitelaw 1974).

Variations in $\mathrm{CO}_{2}$ production were as depicted in Fig. 1. The lowest values were observed in corrals before the activity $[650 \pm 27.1 \mathrm{ml}$ hour $\left.^{-1} \cdot\left(\mathrm{kg} \mathrm{BW}^{0.75}\right)^{-1}\right]$ and on the short walk of 1 kilometer at 1 $\mathrm{km} /$ hour ${ }^{-1}(722 \pm 48.8)$. These values were not significant $(\mathrm{p}>0.1)$. The highest level of $\mathrm{CO}_{2}$ was produced when walking on the gra-

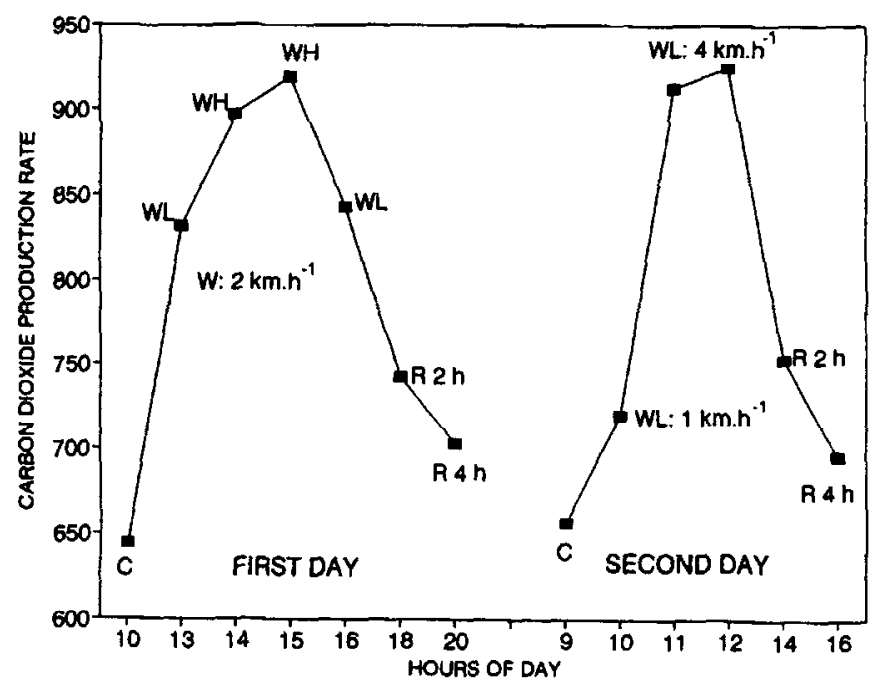

Fig. 1: Variations in $\mathrm{CO}_{2}$ production rate ( $\mathrm{ml}$ hour ${ }^{-1} . \mathrm{kg} \mathrm{BW}^{\circ .75}$ ) in 7 steers in corrals (C), walking $(W)$ on the level ground $(L)$ at 1,2 , and $4 \mathrm{~km} /$ hour, on a $6 \%$ grade $(H)$ and at 2 and 4 hours of rest (R). dient or on level ground at $4 \mathrm{~km}$ hour ${ }^{-1}$. The increases in $\mathrm{CO}_{2}$ when walking at 2 and $4 \mathrm{~km}$.hour ${ }^{-1}$ on the level ground [ $837 \pm$ 26.3 and $919 \pm 40.0$, ml.hour $^{1}$. $\left(\mathrm{kg} \mathrm{BW}^{0.75}\right)^{-1}$, respectively] as well as on the grade $(908 \pm 40.9)$ were significantly different from those in corrals $(p \leq 0.1)$. However differences due to walking at 2 and $4 \mathrm{~km}$.hour ${ }^{-1}$ on the flat, and on the $6 \%$ gradient were not significant $(p>0.1)$.

\section{Energy Expenditure}

It is important to bear in mind that an estimate of $\mathrm{CO}_{2}$ entry rate, whether derived from blood, urine, or exhaled gas samples, is not necessarily an absolute measure of the rate of $\mathrm{CO}_{2}$ production either by the body tissues or the whole animal. It is a practical index of heat production (HP) or energy expenditure (Corbett et al. 1971) that depends on the energy equivalent of $\mathrm{CO}_{2}$ which varies with the type of fuel being oxidized. Whitelaw (1974) pointed out that HP derived directly from the ${ }^{14} \mathrm{C}$ entry-rate and the appropriate energy equivalent of $\mathrm{CO}_{2}$, is as accurate as other published equations. Thereforc, such approach was used in the present experiment, assuming an energy equivalent of $5.26 \mathrm{kcal}$ liter ${ }^{-1}$ of $\mathrm{CO}_{2}$ (Sahlu et al. 1988; Elia et al. 1988). It is important to point out that estimations from this procedure agree very well with published prediction equations for sheep by Sahlu et al. (1988) and for cattle by Young (1970).

Differences in energy expenditure in both mornings in corrals before activity, or in 2 moments under the same level or intensity of activity were very small and had standard errors of each estimation between 3 to $8 \%$ (Table 1), in accordance with Young (1970), Whitelaw (1974), and Havstad and Malechek (1982), who reported mean standard errors of 7 to $20 \%$. The coefficient of variations in the present study were between 8 to $19 \%$ of the mean.

Table 1: Energy expenditure of 7 steers in 2 moments in corrals or under the same level of activity.

\begin{tabular}{lccc}
\hline \hline Condition & Mean EE & $\begin{array}{c}\text { Standard } \\
\text { error }\end{array}$ & $\begin{array}{c}\text { Coefficient } \\
\text { of variation }\end{array}$ \\
\hline In corrals & kcal.hour ${ }^{-1} .100 \mathrm{~kg} \mathrm{BW}^{-1}$ & & $(\%)$ \\
$\quad$ Day 1 & $81.8 \mathrm{a}$ & 3.9 & 13 \\
$\quad$ Day 2 & $83.4 \mathrm{a}$ & 4.8 & 15 \\
Walking 2 km.h & & & \\
$\quad$ First km & $105.6 \mathrm{~b}$ & 3.1 & 8 \\
$\quad$ Fourth km & $107.4 \mathrm{~b}$ & 3.9 & 10 \\
Walking 4 km.h-1 & & & \\
$\quad$ First 2 km & $115.8 \mathrm{~b}$ & 5.1 & 12 \\
$\quad$ Second 2 km & $117.3 \mathrm{~b}$ & 5.2 & 12 \\
Walking on the grade & & & \\
$\quad$ Ascending & $113.7 \mathrm{~b}$ & 8.1 & 19 \\
$\quad$ Descending & $116.5 \mathrm{~b}$ & 6.0 & 14 \\
\hline
\end{tabular}

a,b: Means followed by different letters are significant $(p \leq 0.1)$.

The average energy expenditure of both mornings standing in the corrals before the different periods of activity $(n=14)$ was $82.6 \pm 3.1 \mathrm{kcal}^{-1}$ hour ${ }^{-1} .100 \mathrm{~kg} \mathrm{BW}^{-1}$ as shown in Table 2 . The increase of $\mathrm{EE}$ was 11,29 , and $40 \%$ walking at 1,2 , and $4 \mathrm{~km}$ hour ${ }^{-1}$ (or on the grade), respectively $(8.7,23.9$, and $32.9 \mathrm{kcal}$ hour $\left.{ }^{-1} .100 \mathrm{~kg} \mathrm{BW}^{-1}\right)$. With the exception of walking at $1 \mathrm{~km}$ hour $^{-1}$, EE expenditure increased significantly $(p \leq 0.1)$ above the level observed in corrals when walking. However, effect of walking at 
Table 2: Energy expenditure for steers in corral and walking (in kcal.hour ${ }^{-1} .100 \mathrm{~kg} \mathrm{BW}^{-1}$ ).

\begin{tabular}{|c|c|c|c|c|c|}
\hline \multirow{2}{*}{$\begin{array}{l}\text { Walking pace } \\
\left(\mathrm{km}^{\left.- \text {hour }^{-1}\right)}\right.\end{array}$} & \multirow{2}{*}{$\begin{array}{c}\text { Surface } \\
\text { type }\end{array}$} & \multirow[t]{2}{*}{$\mathrm{EE}$} & \multirow[t]{2}{*}{ Observations } & \multicolumn{2}{|c|}{--Increase ${ }^{c}--$} \\
\hline & & & & (EE) & (\%) \\
\hline 0 & Corral & $82.6 \mathrm{a} \pm 3.1$ & 14 & --- & - \\
\hline 1 & Level & $91.3 \mathrm{a} \pm 5.2$ & 6 & $8.7 \mathrm{a}$ & 11 \\
\hline 2 & Level & $106.4 \mathrm{~b} \pm 2.6$ & 13 & $23.9 b$ & 29 \\
\hline 2 & $6 \%$-grade & $115.1 \mathrm{~b} \pm 5.1$ & 14 & $32.6 \mathrm{~b}$ & 39 \\
\hline 4 & Level & $116.6 \mathrm{~b} \pm 3.7$ & 14 & $33.1 b$ & 41 \\
\hline
\end{tabular}

a,b Means followed by different letters are significant $(\mathrm{p}<0.1)$.

$c$ Increase in energy expenditure relative to standing in a corral

$2 \mathrm{~km} \mathrm{hour}^{-1}$ (on level ground and on the $6 \%$ grade) or at $4 \mathrm{~km}$ hour $^{-1}$ were not different ( $p>0.1$ ) among themselves (Table 2). The lack of significance could be attributed mainly to the small relative differences in rate of $\mathrm{CO}_{2}$ production among periods of activity, which were below, or close to, the limit of significance of $15 \%(P \leq 0.1)$ that this methodology was able to detect under the conditions of the present experiment.

When the speed was duplicated from 1 to 2 and from 2 to 4 $\mathrm{km}$.hour ${ }^{-1}$ EE increased 18 and $12 \%$, respectively, which is partially in accordance with Ribeiro et al. (1977) who reported that when walking speed on the treadmill increased from 2.4 to 5 km.hour ${ }^{-1}$ EE augmented $18 \%$ in young cattle. However, they also found in their study that older cattle exhibited a minimum of EE when walking at a speed of $3.3 \mathrm{~km}$ hour ${ }^{-1}$, which means that EE increased when animals walked at higher or lower speeds.

The maximum increase of energy expenditure of $40 \%$ observed in the present study is in agreement with those reported by Havstad and Malechek (1982) in grazing heifers (46\%) and by Maloiy et al. (1986) in African women (47\%) carrying a load of $61 \%$ of their body mass on a treadmill. One is tempted to speculate that this maximum increase of energy expenditure of 40 to $50 \%$ above the no-activity level could be indicating same physiological limit of aerobic capacity.

The energy cost of walking on the level ground (y) estimated by regression of heat production (Fig. 2) and the speed (x) was: $y$ $=84.4+9 x\left(S_{b}=1.14, S_{y}=12.63, R^{2}=0.53\right)$. The average cost of walking on the $6 \%$ grade was $16.4 \pm 2.18 \mathrm{kcal}^{-1} \mathrm{~km}^{-1} .100 \mathrm{~kg}$ $\mathrm{BW}^{-1}$ with no significant differences between ascending and descending the $6 \%$ grade.

\section{Residual Effect of Activity}

After walking was terminated the rate of $\mathrm{CO}_{2}$ production fell rapidly to the level before activity, following a similar pattern of decline on both days (Fig. 1). After 2 hours of rest, the rate of carbon dioxide production decreased to a level that was not significantly different from the level previous to exercise. There was a $10 \%$ not significant cumulative effect during 4 hours after walking that returned to the baseline observed in corrals after 1 night of rest, therefore the $\mathrm{CO}_{2}$ production of the second morning was similar to that on the first morning. Corbett et al. (1971) observed that the $\mathrm{CO}_{2}$ entry rate in sheep returned to a baseline 76 minutes after a 3 hour walking interval ended ( $\left.1.5 \mathrm{~km} \mathrm{hour}^{-1}\right)$. Clapperton (1964) reported that the energy expenditure of sheep at night was unaffected by considerable differences in their level of activity by day, and that energy expenditure during the night following the exercise, could decrease because animals tend to lie more during the period of rest. The above author, also pointed out that an increase in the rate of $\mathrm{CO}_{2}$ production during the night could have happened only if animals failed to recover from the effect of exercise and enter into the night in a state of oxygen debt.

There was no difference in EE between the first and fourth walking interval at $2 \mathrm{~km}$ hour $^{-1}$ on the level (Table 1). As depicted on Fig. 1, $\mathrm{CO}_{2}$ production was similar when the steers walked the first kilometer at $2 \mathrm{~km}$.hour ${ }^{-1}$ (interval 1) than when they walked the fourth kilometer (interval 4 ) on the way back to corrals [832 vs $843 \mathrm{ml} \mathrm{hour}^{-1}\left(\mathrm{~kg} \mathrm{BW}^{0.75}\right)^{-1}$ ]. In this last walking interval animals had previously walked $1 \mathrm{~km}$ on the level plus 2 $\mathrm{km}$ ascending and descending the $6 \%$ grade.

The 1-hour-walking interval at $4 \mathrm{~km}$ hour $^{-1}$ was divided in 2 periods of 30 minutes each to examine whether severe exercise in the preceding first 30 minutes affected the $\mathrm{CO}_{2}$ production of the next 30 minutes ( $2 \mathrm{~km}$ each interval). As shown in Table 1, no differences $(1.3 \%)$ were found in EE within this walking interval. Results clearly indicate that there was no carry over effect of the exercise from one day to the next, or between and within walking intervals.

\section{Effect of Walking on Energy Requirement}

As mentioned earlier most estimations of how much walking could affect cattle energy requirement are derived from data of Ribeiro et al. (1977), who measured $\mathrm{O}_{2}$ consumption of 4 steers walking on a treadmill at speeds between 2 to $5 \mathrm{~km}$ hour ${ }^{-1}$. They concluded that on the average the energy cost was $50 \mathrm{kcal}^{-\mathrm{km}^{-1}} .100$ $\mathrm{kg} \mathrm{BW}^{-1}$. However, Corbett et al. (1971) reported an energy cost of walking in 3 sheep walking at $1.5 \mathrm{~km}$ hour $^{-1}$ of is approximately

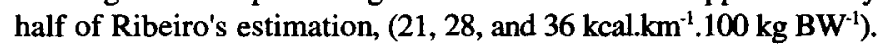
In the present study the cost of walking was 9.0 and $16.4 \mathrm{kcal} \mathrm{km}^{-1} .100$ $\mathrm{kg} \mathrm{BW}^{-1}$, on the level and on a $6 \%$ grade, respectively. A previous study from our lab (Méndez et al. 1996) using this methodology showed an energy cost of steers walking at $3 \mathrm{~km}$ hour ${ }^{-1}$ of approximately $16 \mathrm{kcal}^{\mathrm{km}} \mathrm{km}^{-1} .100 \mathrm{~kg} \mathrm{BW}^{-1}$.

Although data in the present study are the lowest reported in literature, they agree well with estimations of Nicholson (1987) who calculated, from body weight loss, an energy cost of walking

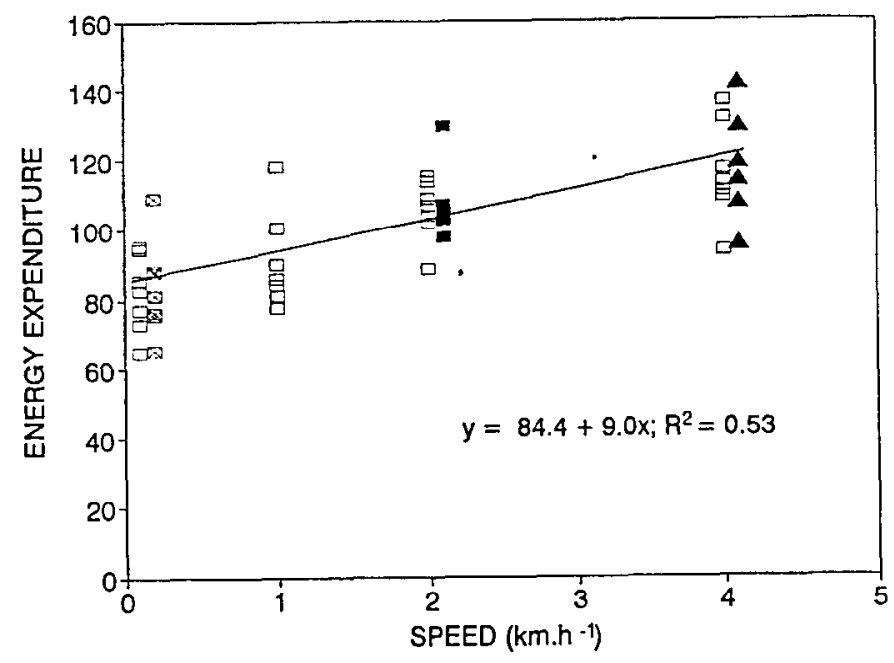

Fig. 2: Energy expenditure (kcal.hour ${ }^{-1} .100 \mathrm{~kg} \mathrm{BW}^{-1}$ ) of steers walking on the level ground at different speeds.

Empty square: day 1 in corral or walking at 1, 2, or 4 km.hour ${ }^{-1}$ Square with x: day 2 in corrals

Filled square: After walking at $2 \mathrm{~km}$.hour ${ }^{-1}$ on the $6 \%$ grade Triangles: replicated samples during the $4 \mathrm{~km}$ walking interval 
in zebu cattle of $11.4 \mathrm{kcal}^{-1} .100 \mathrm{~kg} \mathrm{BW}^{-1}$. This author assumed that the low energy cost of walking observed in his research could have been the result of a lower basal metabolic rate post-activity. However, our data indicate that the rate of $\mathrm{CO}_{2}$ production after walking was similar and not lower than that previous to the activity. Gemeda et al. (1995) also found minor differences in body weight losses and milk production between working and non-working cows, and Zerbini et al. (1995) reported that working increases the utilization of food energy in dairy cattle. In addition, Mulligan and Butterfield (1990) have reported that women who performed strenuous physical activity $(54 \mathrm{~km}$ week $^{-1}$ ) maintained weight even that EE exceed intake by 645 $\mathrm{kcal}_{\text {day }}{ }^{-1}$. Data appears to indicate that walking in the open at a constant speed is a low energy-cost process possibly overestimated in experiments carried out on treadmills. Zimmer (1995) pointed out that in walking humans $65 \%$ of the forward movements turns into kinetic energy which is transferred into the next step. Only the remaining $35 \%$ is lost and has to be made up by muscles converting food energy into kinetic energy.

Results from the ${ }^{14} \mathrm{C}$ turnover of the present experiment indicate that the extra cost required for travelling $6 \mathrm{~km}$ on the level ground at $9 \mathrm{kcal}^{-1 \mathrm{~km}^{-1} .100 \mathrm{~kg} \mathrm{BW}} \mathrm{kW}^{-1}$ is approximately $54 \mathrm{kcal} .100$ $\mathrm{kg} \mathrm{BW}^{-1}$. This increase of EE represents, over a 24 hour period, $3 \%$ above the $82.6 \mathrm{kcal}^{-1}$ hour ${ }^{-1} .100 \mathrm{~kg} \mathrm{BW}^{-1}$ observed in corrals [54/(82.6*24)]. This estimation is in agreement with data of Méndez et al. (1996) who reported an increase of $4 \%$ in steers walking $6 \mathrm{~km}$ at $3 \mathrm{~km}$ hour ${ }^{-1}$. Such small increment in EE could only have a minor effect on the energy requirement of grazing cattle. Therefore, the improvement of cattle production observed when pasture size is reduced, or additional watering points provided, cannot be the result of the energy saved due to the reduction of the distance travelled. It is more likely that such result could be the consequence of a better pasture management achieved by means of the proper stocking rate and even livestock distribution that assures more uniform grazing (Hart et al. 1993) and in consequence a higher level of nutrition.

\section{Conclusions}

The turnover of ${ }^{14} \mathrm{C}$ indicates that walking at constant speed on open range is a low energy-cost process that requires approximately 9 and $16 \mathrm{kcal} 100 \mathrm{~kg} \mathrm{BW}^{-1}$ to travel $1 \mathrm{~km}$, on the level ground and on a gradient, respectively. This estimate is much lower than currently used values of 45 to $60 \mathrm{kcal} .100 \mathrm{~kg} \mathrm{BW}^{-1}$ derived from experiments on treadmills. This low cost of travelling may have a small or negligible impact on the energy requirements of grazing cattle. Therefore, shortening the distance travelled by animals on pastoral systems does not seem to represent a saving of energy that per se could increase animal production.

\section{Literature Cited}

Aello, M.S. and P.O. Gómez. 1984. Time and patterns of grazing of Hereford steers on Agropyron elongatum pasture. Rev. Argentina Prod. Anim. 4:533-546.

Agricultural Research Council (ARC). 1980. The nutrient requirements of ruminant livestock. Commonwealth Agricultural Bureaux, Farnham Royal.

Clapperton, J.I. 1964. The energy metabolism of sheep walking on the level and on gradients. Brit. J. Nutr. 18:47-54.

Commonwealth Scientific and Industrial Research Organization (CSIRO). 1990. Feeding Systems for Australian Livestock: Ruminants. CSIRO Publications, Melbourne, Australia.

Corbett, J.L., D.J. Farrell, R.A. Leng, G.L. McClymont, and B.A. Young. 1971. Determination of the energy expenditure of penned and grazing sheep from estimates of carbon dioxide entry rate. Brit. J. Nutr. 26:277-291.

Elia, M, N. Fuller, and P. Murgatroyd. 1988. The potential use of the labelled bicarbonate method for estimating energy expenditure in man. Proc. Nutr. Soc. 47:247-258.

Engels, E.A.N., M.W. Inskip, and J.L. Corbett. 1976. Effect of change in respiratory carbon dioxide entry rate in sheep and their energy expenditure. Publ. Eur. Assoc. Anim. Prod. 19:339-342.

Farrell, D.J., R.A. Leng, and J.L. Corbett. 1972. Undernutrition in grazing sheep. II-Calorimetric measurements on sheep taken from pasture. Aust. J. Agr. Res., 23:499-509.

Gemeda, T., E. Zerbini, A.G. Wold, and D. Demissie. 1995. Effect of draught work on performence and metabolism of crossbred cows. 1 . Effect of work and diet on body-weight change, body condition, lactation, and productivity. Anim. Sci. 60:361-367.

Graham, N.McC. 1964. Energy costs of feeding activities and energy expenditure of grazing sheep. Aust. J. Agr. Res. 15:969-973.

Hart, R.H., J. Bissio, M.J. Samuel, and J.W. Waggoner, Jr. 1993. Grazing systems, pasture size, and cattle grazing behavior, distribution, and gains. J. Range Manage. 46:81-87.

Havstad, M. and J.C. Malechek. 1982. Energy expenditure by heifers grazing Crested Wheatgrass of diminishing availability. J. Range Manage. 35:447-450.

Herbel, C.H. and A.B. Nelson. 1966. Activities of Hereford and Santa Gertrudis cattle on a southern New Mexico Range. J. Range Manage. 19:173-176

Lamb, R.C., B.O. Barker, M.J. Anderson, and J.L. Walkers. 1979. Effect of forced excercise on two-year-old Holstein heifers. J. Dairy Sci. 62:1791-1797.

Lathrop, W.J., D.D. Kress, K.M. Havstad, D.E. Doornbos, and E.L. Ayers. 1988. Grazing behavior of rangeland beef cows differing in milk production. Appl. Anim. Beh. Sci. 21:315-327.

Maloiy, G.M.O., N.C. Heglund, L.M. Prager, G.A. Cavagna, and C.R. Taylor. 1986. Energetic cost of carrying loads: have African women discovered an economic way?. Nature 319:668-669.

Méndez, D.G., O.N. Di Marco, and P.M. Corva. 1996. Energy expenditure of cattle walking on a flat terrain. Anim. Sci. 63:39-44.

Mulligan, K. and G.E. Butterfield. 1990. Discrepancies between energy intake and expenditure in physically active women. Brit. J. Nutr. 64:23-36.

Nicholson, M.J. 1987. Effects of night enclosure and extensive walking on the productivity of zebu cattle. J. Agric. Sci. (Camb.) 109:445-452.

Osuji, P.O. 1974. The physiology of eating and the energy expenditure of the ruminant at pasture. J. Range Manage. 27:437-443.

Ribeiro, J.M. de C.R., J.M. Brockway, and A.J.F. Webster. 1977. A note on the energy cost of walking in cattle. Anim. Prod. 25:107-110.

Sahlu, T., H.G. Jung, J.A. Nienaber, and J.G. Morris. 1988. Development and validation of a prediction equation estimating heat production by carbon dioxide entry rate technique. J. Anim. Sci. 66:2036-2043.

Sanchez, M.D. and J.G. Morris. 1984. Energy expenditure of beef cattle grazing annual grassland. Can. J. Anim. Sci. 64 (Suppl.):332-334.

Thomson, N.A. and M.L. Barnes. 1993. Extra walking: Effect on dairy production. Proc. New Zealand Soc. Anim. Prod. 53:69-72.

White, R.G. 1993. Energy expenditure of ruminants on pasture. World Conf. Anim. Prod., Edmonton, Canada, 475-498.

Whitelaw, F.G. 1974. Measurement of energy expenditure in the grazing ruminant. Proc. Nutr. Soc. 33:163-172.

Young, B.A. 1970. Application of the carbon dioxide entry rate technique to measurements of energy expenditure by grazing cattle. Publ. Eur. Assoc. Anim. Prod, 13:237-241.

Zerbini, E., T. Gemeda, A.G. Wold, S. Nokoe, and D. Demissie. 1995. Effect of draught work on performance and metabolism of crossbred cows. 2. Effect of work on roughage intake, digestion, digesta kinetics, and plasma metabolites. Anim. Sci. 60:369-378.

Zimmer, C. 1995. Biomechanics watch. Discover, August, p.28. 